DOI: $10.15290 /$ bsl.2018.13.08

\title{
Emilia Gałczyńska
}

Wydział Filologii Polskiej i Klasycznej

Uniwersytetu im. Adama Mickiewicza w Poznaniu

e-mail: egalcz@gmail.com

ORCID: 0000-0003-4324-2141

\section{Somato/spacjo/grafie - przestrzeń pomiędzy w twórczości Małgorzaty Lebdy}

Nie ma innego dostępu do ciała niż poprzez język ${ }^{1}$

Geografia przestrzeni jest geografią miejsc połączonych ${ }^{2}$

I.

Małgorzata Lebda, poetka urodzona w beskidzkiej wsi Żeleźnikowa Wielka, w swojej twórczości ukazuje podmiot przebywający w nieustannym ruchu. Paradoksalnie, ciągle powraca on do lat przeszłych i przestrzeni dobrze rozpoznanej, w której jednak nigdy nie dochodzi do ponownego zadomowienia. Poetyckim projektem autorki jest chęć usłyszenia i opowiedzenia historii własnych, minionych. Nieustanne wędrówki z każdym kolejnym tomem, wierszem i wersem uświadamiają czytelnika, że jest współtowarzyszem jednej i tej samej podróży. Jej cel (nigdy w pełni zrealizowany) to chęć dotarcia do pamięci o ciele i przestrzeni (anty)arkadii ${ }^{3}$, które zostają zapisane, aby mogły raz jeszcze zaistnieć jako somato/geo/grafie.

\footnotetext{
${ }^{1}$ J. Bator, Posłowie. Ciała anamorficzne. Kilka uwag filozoficznych, w: Ucieleśnienia. Ciało w zwierciadle wspótczesnej humanistyki. Myśl-praktyka-reprezentacja, red. A. Wieczorkiewicz i J. Bator, Warszawa 2007, s. 299.

2 T. Sławek, Gdzie, w: Oikologia. Nauka o domu, red. T. Sławek, A. Z. Kadłubek, A. Kunce, Katowice 2013, s. 9.

${ }^{3} \mathrm{~W}$ pracy omawiam trzy tomiki wierszy (nie licząc pierwszego debiutanckiego: Otwarta na 77 stronie), które tworzą poetycki tryptyk. Mowa o: Tropy, Gniezno 2009; Granica lasu, Poznań 2013 (w 2014 nominacja do Nagrody Poetyckiej im. K.I. Gałczyńskiego - „Orfeusz” oraz nomi-
} 
Lebda tworzy spację, którą jednocześnie przepełnia przeszłość i teraźniejszość oraz wspomnienia dotyczące ojca. Pojawiają się rozważania o roli ciała: kobiety, córki oraz siostry. Nie brakuje pytań dotyczących śmierci i choroby, która to pozostawia znaczące znamiona na ciele podmiotu. Wszystkie te kategorie i ich zestawienie wytwarzają przestrzeń pomiędzy 4 .

Poetka dociera do tworzywa artystycznego poprzez doświadczenie cielesne, nie tylko fizyczne, ale także duchowe. Kartezjańska opozycja duszy i ciała przestała być we współczesnych badaniach literackich fundamentem pracy interpretacyjnej, zmiana ta jest skorelowana $\mathrm{z}$ dużo wcześniejszymi odkryciami medycznymi. Tomasz Wiślicz zaznacza:

Sytuacja zmienia się pod wpływem odkryć naukowych z zakresu fizjologii układu nerwowego, który od połowy XVIII w. stał się obiektem zainteresowania wielu wybitnych badaczy. To dzięki pracom Albrechta von Hallera czy Charles'a Bonneta w dyskursie publicznym ostatnich dziesięcioleci XVIII w. pojawiła się kategoria wrażliwości nerwów, a wraz z nią nowy język opisu, skupiony bardziej niż do tej pory na cielesnym rozumieniu podmiotu czującego ${ }^{5}$.

I dalej:

I to chyba nie przypadkiem zainteresowanie anatomią i fizjologią ciała ludzkiego pojawiło się $\mathrm{w}$ społeczeństwach Zachodu równocześnie $\mathrm{z}$ wielkimi odkryciami geograficznymi. Podróż za morze, odkrywanie nowych lądów, znajdowały swoją analogię w podróży do wnętrza ciała ${ }^{6}$.

W humanistyce zafascynowanej możliwościami interpretacji spacjalnej, punktem wyjścia staje się nie tyle nowa opozycja, co niedostrzeżona wcześniej w takiej rozpiętości relacja ciało-przestrzeń. Podmiot wierszy Lebdy uczestniczy w przestrzeni poprzez własną cielesność, która jednocześnie jest doświadczeniem przypominanym - psychicznym. Każdy wiersz to pokorna nauka powracania i opisywania owej relacji, która każdorazowo inaczej konstytuuje się w konkretnym wierszu:

nacja do Nagrody Poetyckiej im. Krystyny i Czesława Bednarczyków) oraz Matecznik, Poznań 2016 (za który poetka otrzymała stypendium Nagrody im. Stanisława Barańczaka, przyznanej w Poznaniu w 2017 roku).

4 Przestrzeń traktuję jako „pojęcie wędrujące”: „pojęcia nie są ustalone. Wędrują one pomiędzy dyscyplinami i między poszczególnymi uczonymi, między okresami historycznymi i między rozproszonymi geograficznie społecznościami uczonych" [M. Bal, Wędrując pojęcia w naukach humanistycznych. Krótki przewodnik, przeł. M. Bucholc, Warszawa 2012, s. 49].

5 T. Wiślicz, Integralność cielesna jednostki w perspektywie przejścia do nowoczesności - zarys problematyki, w: Somatotes. Cielesność w ujęciu historycznym, red. R. Matuszewski, Warszawa 2012, s. 133.

6 Tamże. 


\section{granica lasu}

las czuje pustkę tego domu i próbuje się zbliżyć wysyła młode sarny by obgryzły kruche gałęzie jabłoni przygląda się rozrasta i podchodzi lisem pod stodoły z ciężkich bali musisz wiedzieć że mamy z lasem niedokończone strachy $i$ mgliste historie należy je opowiedzieć stąd te nieustanne spacery nasłuchiwania zbieranie żołędzi wcieranie bzowiny w ciało suszenie grzybów i ziół ${ }^{7}$

W utworze zostaje zestawiona przestrzeń domu i spacja poza nią. Przybliżanie się ucieleśnionego lasu jest nigdy niedokończone. Nie bez powodu pojawia się tu słowo „pustka”, które paradoksalnie charakteryzuje przestrzeń domu. Czy las ma ją wypełnić? Aleksandra Kunce w tekście Puste i domowe rozważa:

Po co nam „puste”? Dlaczego naszej myśli o domu, o lokalności, o nas samych potrzebna jest pustynia? Czy naprawdę pustynia jest kwintesencją tego, co „puste"? Dziwić może to, że człowiek potrafi wytrzymać ciśnienie pustki wokół domu, wszak pustynie to nasze sąsiedztwo. Dlatego konieczna jest próba związania "domowego" i „pustego" 8 .

Autorka podkreśla współistnienie strefy pustynnej i domowej jako kategorii przeciwstawnych, ale sobie potrzebnych. Lebda zaś przenosi znaczenie pustki - tego, co puste, pustynne - do przestrzeni domu. Dzięki poetyckiemu zabiegowi dokonuje zmiany statusu ontologicznego i semantycznego ugruntowanego w kulturze toposu. Las staje się przestrzenią „wypełnioną”, która potrafi uzupełnić braki w domostwie: „Dom to naprawdę grób, bowiem istnieje oczywisty związek domu z ziemią, w której spoczną kości" ${ }^{9}$.

Skoro poetyckie i semantyczne przesunięcie słowa „pustka” odnajduje swoją realizację w przestrzeni domu, możemy powiedzieć, że przestaje ona w wierszu istnieć. Dzieje się tak, ponieważ to, co pustynne jest jednocześnie tym, co domowe, a las (przestrzeń zewnętrzna, która jest nadal niedomowa) nie zastępuje domu.

Kunce w niezwykle interesujący sposób przewartościowuje także oba pojęcia, szczególnie starotestamentowe znaczenie „pustyni” ${ }^{10}$. Pustka i dom

7 M. Lebda, Granica lasu, Poznań 2013, s. 40. Dalej posługuję się skrótem GL, wraz z numerem strony.

8 A. Kunce, Puste i domowe, w: Oikologia, s. 142.

9 Tamże, s. 145.

10 Interesującym kontekstem jest etymologia słowa „puszcza”. W słowniku znajduję: „od XIV w. 'las pierwotny: większy kompleks leśny', daw. 'las, bór', stp. Też 'pustynia', w XVI w. 'miejsce samotne; pustelnia'. [...]" [Stownik etymologiczny języka polskiego, red. W. Boryś, Kraków 2005, s. 505]. 
okazują się tym samym. Porzucając dom-pustkę nie uciekniemy przed jego pustynnością. Pustka przejawia się $\mathrm{w}$ nas i jedynie utożsamianie się $\mathrm{z}$ lasem pozwala ją zniwelować, ale nigdy do końca. Cielesne obcowanie poprzez zmysły z przestrzenią natury może nas wypełnić, jednak nie uzupełni „pustki".

Jedyną drogą do dokończenia rozmów z lasem/o lesie w wierszu granica lasu jest przebywanie, obcowanie $\mathrm{w} / \mathrm{z}$ nim. $\mathrm{W}$ tym porządku interpretacyjnym przestrzeń „stąd” tłumaczy częste spacery i suszenie grzybów oraz ziół, które pozwalają przybliżyć się do magicznego istnienia lasu. Przestrzeń pomiędzy wnętrzem i zewnętrzem domu-lasu, ruchoma i mglista spacja, która czeka na nieustanne opowiadanie, jest realizowana w kolejnych wierszach często $\mathrm{w}$ sposób zasadniczo odmienny. Inaczej także kreowany jest obraz domu:

\section{dom}

był czas kiedy przyjmował nas jak obcych oddalonych a przecież łączyły nas tajemnice trzeszczenia podłóg monety wpychane pod boazerię święte obrazy dymiona pełne winogron a jeśli alkohol to i strach tytoń opary dymu sosnowe żerdzie pod ścianą i zwierzęta znoszone z pobliskiej stodoły ich ślepe pyski pergaminowa skóra $a$ to?

szmery jałowców krwawnik przykładany do ran i nocne narracje które dyktował jørgen moe baśnie baśnie

[GL, s. 10]

W wierszu granica lasu dom jest przestrzenią statyczną wypełnioną pustką. Został on zapewne zbudowany, tak jak stodoła, z ciężkich bali ${ }^{11}$. W kolejnym utworze ożywa dzięki opisaniu osobliwej zwyczajności - pierwiastki magiczne przejawiają się $\mathrm{w}$ zjawiskach łączących przestrzeń domu i osoby go zamieszkujące. Nie nastąpiło to jednak od razu. Dom zostaje oswojony poprzez wspomnienia zlokalizowane wokół przedmiotów użytkowych i codziennych.

W wierszu wybrzmiewają dwa głosy, które należą jednak do tej samej osoby. Interesujący zabieg stylistyczny, zastosowany w większości utworów Lebdy, nie ma na celu uwidocznienia puenty ani stworzenia klamry kompozycyjnej. Autorka nie dąży do napisania tekstu zamkniętego (szczelnie utkanego). Wiersze są utworami otwartymi. Czytając tom Granica lasu, zapoznajemy się z jedną i tą samą historią, opowiadaną z różnych punktów

11 Ciężkie bale to martwe drzewo, które jest pozbawione życia oraz pierwiastków magicznych. 
przestrzennych, przefiltrowaną przez różne świadomości i wrażliwości somatyczne. Ostatnie wersy wiersza mogą zapowiadać kolejny utwór, budować nowe obrazy poetyckie.

Pierwszy głos (odgrodzony od drugiego spacją - przestrzenią milczenia) wypowiada się na temat zjawisk przypisanych do sfery codziennej magiczności. Postać wykreowana w wierszu nie zawsze potrafi odnaleźć swoje miejsce w zastanej rzeczywistości, czuje się obco. Zostaje zaburzony podstawowy fundament zadomowienia, czyli poczucie "bycia u siebie”. Dom okazuje się jedynie świadkiem "dziania się" materialności przedmiotów i życia (ludzkiego, ale przede wszystkim zwierzęcego).

Drugi głos, mówiąc o sferze nad-codziennej, zmienia ton wypowiedzi. W przypadku pierwszego "my” wspomnienia dotyczyły magiczności codziennej i materialnej, w tym zaś fragmencie ujawnia się rytualny i obrzędowy charakter przestrzeni domu i opisanej historii. Nie bez powodu autorka przywołuje "baśnie baśnie" norweskiego pisarza. Utwór, tak jak przytoczona książka, ma charakter bajki ludowej, magicznej baśni ${ }^{12}$. Pierwiastki prywatnej magiczności oraz cudowności, związane z ludowymi wierzeniami i metodami leczniczymi, mieszają się ze sobą, jednak dzięki przestrzeni pomiędzy dostrzegamy ich różne charaktery. Pierwsze opisują dzianie się dnia, drugie - nocy. Pewne elementy utworu odnoszą się także do lokalności:

Lokalna wizja życia nobilituje szczegóły. Tworzy z nich konstrukcje, ale i z łatwością je demontuje. Nie ufa całości. Całość jest dziwnym pojęciem, obejmującym również skończony kształt, zakreśloną granicę, domknięty i samowystarczalny świat ${ }^{13}$.

Świat wiersza pozostaje w procesie wiecznego stawania się i dziania, nobilituje cząstkowość. Las „,szemrze”, jest „przykładany do ran”. Konkretne wymienione przedmioty, relacje z urywków zdarzeń, mówią o fragmentaryczności opisywanej przestrzeni. Autorka zapytuje ",a to?", pragnie uporządkować każdy otaczający ją element. Próby memorialne, związane z chęcią zrozumienia, stają się migawkami wspomnieniowymi, które wywołują

12 L. Żuliński pisał w recenzji tomiku Granica lasu: „Ten dom, to dzieciństwo - to kraina baśni. Sennej, ale nie beztroskiej. Baśni pięknej, lecz poniekąd Andersenowskiej, w której złe duchy i ezoteryczne fluidy krążą pod powałą lub wciskają się pod dziecięcą poduszkę. Jakieś szczegóły, jakieś epizody, powidoki mniej lub bardziej realne, lecz zakorzenione od lat w pamięci powracającej z dalekiego, ciemnego lasu [...]" [L. Żuliński, Mesmeryzmy, „Latarnia Morska”, 20.01.2014, http://latarnia-morska.eu/en/port-literacki/1428-qgranica-lasuq-magorzaty-lebdy, dostęp 02.03.2017].

13 A. Kunce, Dom - na szczytach lokalności, w: Oikologia, s. 67. 
chwilę zwątpienia i zdziwienia. Może zapytanie odnosi się do zwierzęcia, które jest „znoszone”? Należy ono do przestrzeni materialnej, postać nie zadaje przecież pytania: „a kto”? Elementarność, fragmentaryczność, niecałościowe ujęcie charakterystyczne dla wspomnień, istnieje dzięki konkretnemu punktowi widzenia, patrzeniu z konkretnej przestrzeni:

bliskie jest mi patrzenie na antropologię lokalności przez pryzmat punktu. Bo punctum, jak podpowiada etymologia, to nie tylko punkt czasoprzestrzeni, punkt zapisu, punkt oznaczeń - punctum kłuje, staje się stygmatem, znakiem, przyjmuje konkretną postać wyrytą na ciele niewolnika, jest wreszcie wiązką relacji. Otwiera przestrzeń tego, co rani, ale i porusza nas do głębi. Każda lokalność porusza do głębi. I w końcu rani ${ }^{14}$.

I dalej:

Lokalność miałaby kształt tego, co filozofowie mogliby nazwać przylgnięciem do życia, które musi być namacalne i uchwytne tu i teraz ${ }^{15}$.

Punkty widzenia zostają osadzone we wspomnianych "fragmentach pamięci". Wszystkie obrazy są budowane, tak jak w poprzednim wierszu, na podstawie sensorycznych doświadczeń. Materialną sferę przysłania cielesność. „Tajemnica trzeszczenia podłóg” zostaje rozpoznana poprzez konkretny ruch. Tytoń i alkohol są używkami cielesnymi, uciechami ciała, które mogą stać się „strachem”. I w końcu zwierzęta - ich ciała traktowane są jak przedmioty, okazują się ofiarami lokalności, bezwładnie, ale cieleśnie „znoszone" do domu. Lokalność rani. Tu i teraz.

Dom i to, co lokalne, podzielone zostaje $\mathrm{w}$ wierszu na sferę magiczności materialnej i rytualnej. Obie zaś sfery budują przestrzeń wiecznie odżywającą, cieleśnie zapamiętaną, ale także odchorowaną i przebolałą. Czytanie „baśni baśni" wcale nie odgradza postaci wiersza od opisanej rzeczywistości. Pozwala jej na powtórne zakotwiczenie się w otaczającej nadrealności.

Wraz z poznawaniem reguł natury, objaśnianych przez ojca w kolejnych tekstach, dom traci swoją autonomię i przestaje funkcjonować jako epicentrum. We wspomnieniu-wierszu studnia, przestrzeń staje się impulsem do budowania narracji o charakterze egzystencjalnym:

14 Tamże, s. 67-68.

15 Tamże, s. 66. 


\section{studnia}

wkładaliśmy w usta jesień a jej cierpki smak krzywił nasze gładkie twarze był to czas palenia naci pieczenia dojrzałych warzyw w rozgrzanej brandrurze grzmoty odeszły a z nimi niepokój nastała cisza przed zimą winogrona oplotły drzewa i dach stodoły a ich ciemne grona dochodziły w szklanych dymionach dlaczego właśnie wtedy przyciągała nas otwarta studnia ta czarna tafla do której ojciec kilka lat wcześniej wrzucił tajemniczą rybę a z której wszystkie nasze tłuste zwierzęta piły krystaliczny chłód?

to właśnie wtedy do niej wiosną wpadła stara rogowska podobno czasem słychać tam świsty cały jej strach

[GL, s. 14]

Logiką wiersza rządzą metody mnemotechniczne, ale też reguły pamięci mimowolnej. Wspominanie staje się impulsem do porządkowania przestrzeni lat dziecinnych/młodzieńczych, kiedy świat wydaje się najbardziej wypełniony sensorycznymi doznaniami. Taki jest również utwór studnia, w którym, dzięki licznym przerzutniom (opanowanym przez autorkę do perfekcji), w zależności od tego, jak je potraktujemy, możemy przeczytać dwie poetyckie historie. To wiersz kalejdoskopowy: budzi migotliwe obrazy, nieustannie poddawane próbie odzyskania. Utwór mówi o pracy pamięci, o tym, że finalnie zapamiętujemy szczegóły, które dla większości są niezauważalne. Dla podmiotu zaś coroczne czynności wykonywane wraz z nadejściem jesieni jawią się jako obrządki magiczne.

Nastrój wiersza w dwóch ostatnich wersach ulega radykalnej zmianie. Możemy interpretować „przerzutnię nastrojowości” jako kolejną cechę procesu przypominania. "Stara rogowska” to postać często występująca w tomie. Nie bez przyczyny jej nazwisko (tak, jak każdej przywoływanej osoby w książce) pisane jest małą literą. Nie opisujemy konkretnej postaci, ale jej typ: "stara rogowska” zostaje utożsamiona z zabobonnym charakterem wsi. W tym wypadku funkcjonuje jako element opowiadanej dzieciom historii-baśni, którą dorośli wykorzystują, aby je przestraszyć.

W wierszu można też dostrzec elementy groteski, odrealniające poetycki świat Lebdy. Pojawienie się „tajemniczej ryby" potwierdza baśniowy charakter utworów. Przestrzeń, na skutek poetyckich zabiegów, traci znamiona realności, magiczność jednak funkcjonuje na innych zasadach, niż w poprzednich wierszach.

Przestrzeń zostaje „uporządkowana” dzięki elementom krajobrazu, które pobudzają kolejne wspomnienia. Przerzutnie i praca pamięci stwarzają wiersz tektoniczny, za każdym odczytaniem kreując nowy obraz. Syneste- 
zja potęguje nastrój wiersza, mówi o cielesnym charakterze pamięci (pamiętamy to, co odczute sensorycznie, cieleśnie). Anna Łebkowska w artykule Jak ucieleśnić ciało: o jednym $z$ dylematów somatopoetyki pisała:

Otóż obecnie w synestezji cielesność, a właściwie specyficzna relacja między tym, co somatyczne, a tym, co semantyczne, tym, co niewerbalne, a tym, co wysławialne, wysuwa się na plan pierwszy, przy czym podkreśla się zakotwiczenie zmysłów w cielesności właśnie. Synestezję docenia się przede wszystkim za to, że pozwala połączyć doznania zmysłowe ze znaczeniem, somatyczne z tym, co językowe, że ucieleśnia w sobie to, co sensualne, w sobie tylko właściwy sposób, nie umykając temu, co powiązane $\mathrm{z}$ sensem $[\ldots]^{16}$.

Synestezyjne doznania pozwalają na proustowskie próby nie tyle odzyskania, ale zapisania przestrzeni. $W$ wierszu dominuje zmysł wzroku. Poznajemy smak jesieni poprzez jej detaliczny opis, liczne przymiotniki („gładkie twarze”, „dojrzałe warzywa”, „rozgrzana brandrura”, "ciemne grona”, "szklane dymiona”, „otwarta studnia", „czarna tafla”, "tajemnicza ryba”, "tłuste zwierzęta", ,krystaliczny chłód", „stara rogowska”). Wyliczenie uwidocznia zwykłość opisywanych przedmiotów, a także bohaterów wiersza (zwierzęta, "stara rogowska"), jednak zestawienie w konkretnych konstelacjach synestezyjnych nadaje im wydźwięk niesamowitości, oryginalności i magiczności. Również użycie rzadkich wyrazów, takich jak brandrura i dymiona, które należą do gwary ludowej, nie jest przypadkowe - wprowadzają one czytelnika w stan uważności na słowa oraz sam świat wiersza.

W utworze opisane jest somatyczne złączenie się postaci z zastaną przestrzenią: „wkładaliśmy w usta jesien". Pora roku stała się częścią ciała, granica pomiędzy nią a spacją zatarła się. Zanika także granica czasu. Wspomnienia i teraźniejszość zaczynają współistnieć. Przyroda, tak jak w wierszu granica lasu, przybliża się ciemnymi gronami winogron do podmiotu. Później zostaną one wypite, dojdzie zatem do kolejnego złączenia przestrzeni i ciała.

Synestezyjny charakter wiersza moglibyśmy nazwać także symbiotycznym, ale autorka nam na to nie pozwala. Początkowy opis zwykłości (który ma jednocześnie charakter magiczny) ulega zmianie. Pojawia się tytułowa studnia - przestrzeń niewidoczna dla oczu, gdyż nie można objąć wzrokiem jej głębokości. Zmysł zawodzi, pozostają wyobrażenia, których autorem jest ojciec. To on, poprzez opowiadanie historii, cały czas sprawuje kontrolę nad spostrzeganą przez swoje dzieci przestrzenią. "Stara rogowska” wpada do baśniowej studni i chociaż nic nie widać, można nasłuchiwać: „świsty cały jej

16 A. Łebkowska, Jak ucieleśnić ciało: o jednym z dylematów somatopoetyki, „Teksty Drugie” 2011, nr 4, s. 26-27. 
strach". Znamienne okazują się słowa Heideggera, cytowane przez Tadeusza Sławka:

Wygłaszając swój wykład w Darmstadtcie, Heidegger zaprasza słuchaczy do pomyślenia o starym moście w Heidelbergu, do „wmyślania się w tamto miejsce” konkludując: „Możemy nawet być z tutejszej perspektywy daleko bliżej tamtego mostu i tego, co on urządza, niż ktoś, kto obojętnie wykorzystuje go co dzień do przechodzenia przez rzekę"17.

Podmiot wierszy tomu poetyckiego Granica lasu poznaje świat swoim ciałem i zmysłami. Przestrzeń wspomina poprzez zapamiętane barwy, smak, dźwięk i materię. Dzięki utworom Lebdy przekraczamy most czasu, granice przestrzenne i cielesne, wstępujemy jako czytelnicy do baśniowych sfer dzieciństwa. W tym poetyckim świecie nic nie jest na pewno, wszystko czeka na nieustanne odczytania-odczuwania i sensoryczną lekturę.

\section{II.}

Pierwotność w utworach Lebdy ulega licznym przeobrażeniom, stając się też specyficzną poetyką. Jej osiemnastowieczne rozumienie jest we współczesnej humanistyce często powracającym zagadnieniem o charakterze operacyjnym. Rozważania wokół natury oraz człowieka, który za sprawą kultury i techniki się od niej oddalił, nie wystarczą, aby oddać znaczenie pierwotności. Potrzebne są dwie kategorie - ciała i przestrzeni:

Związek między nową filozofią przyrody i estetyką przyrody jest jednak głębszy. W gruncie rzeczy chodzi o „usytuowanie człowieka w otoczeniach”. [...] potencjał tych zmian zaczyna się odczuwać na własnym ciele. Uświadamiają mu to, że on sam jako zmysłowa istota cielesna żyje $\mathrm{w}$ środowiskach, i zmusza go do ponownego włączenia swojej własnej naturalności do obszaru swojej samowiedzy. Samo „usytuowanie w otoczeniach” może stać się jednym z podstawowych tematów estetyki ${ }^{18}$.

Gernot Böhme wykracza poza vikiańskie rozumienie poety pierwotnego. Stwarza własny projekt (włączając kategorie estetyki) ${ }^{19}$, w którym nie zajmuje

\footnotetext{
17 M. Heidegger, Odczyty i rozprawy, przeł. J. Mizera, Kraków 2002, s. 138. Cyt. za: T. Sławek, Gdzie?, w: Oikologia, s. 10.

18 G. Böhme, Filozofia i estetyka przyrody. W dobie kryzysu środowiska naturalnego, przeł. J. Merecki, Warszawa 2002, s. 6.

19 Mowa o ekologicznej estetyce przyrody, która ma charakter pragmatyczny: „Ekologicznie
} 
się jedynie pięknem sztuki, ale także przyrody. Aby dotrzeć do doświadczenia estetycznego, mającego charakter zmysłowy, potrzebny jest kontakt ciała z przestrzenią. Dochodzi do złączenia się omawianych kategorii (wewnętrznej - cielesnej, zewnętrznej - przestrzennej). Böhme dokonuje zmian w rozumieniu pierwotności, ponieważ ciało doświadczającego zmysłowo nie musi znajdować się w przestrzeni oświeceniowo rozumianej natury ${ }^{20}$. Może to być również krajobraz miasta. Każda przestrzeń stwarza konkretną atmosferę, mogącą stać się impulsem do doświadczeń cielesnych - tym samym pierwotnych.

Wspomniane samo-uświadomienie (we własnym ciele), staje się kluczem do interpretowania estetycznego ujęcia ciała i przestrzeni. Koncepcja filozofa potwierdza także niesubstancjalny charakter podmiotu, którego „przepracowanie" jest jednak konieczne i ważne:

Wpływ podmiotu na to, czego doświadczamy zmysłowo w otoczeniu, jest jednak istotny. Polega on na przepracowaniu, stylizacji, a przede wszystkim na stłumieniu. Wszystkie te postacie subiektywnej pracy zmysłów zakładają jednak afektywne poruszenie przez otoczenie. Stwierdzenie to prowadzi do przypisania otoczeniu quasi-obiektywnych cech uczuciowych (Gefühlscharaktere) ${ }^{21}$.

Nie tylko nasze ciało, jako pewnego rodzaju „przestrzeń" rezonansowa, wzmacnia doświadczenia zmysłowe (lub dochodzi do ich wyciszenia - zawsze jest to jakieś „,upostaciowienie” tegoż doświadczenia), ale również „zewnętrzna natura” zyskuje podmiotowość i charakter sprawczy. Cechy uczuciowe przypisane przestrzeni autor Filozofii i estetyki przyrody, za Hermannem

motywowaną estetykę można równie dobrze nazwać ogólną teorią postrzegania. [...] chodzi o to, aby do pojęcia postrzegania włączyć ponownie udział emocji, to jest uczuciowe zaangażowanie $\mathrm{w}$ to, co postrzegane, oraz samoorganizację przez spostrzeganie. Jeśli spostrzeganie jest zmysłowym usytuowaniem w otoczeniach [...]" [G. Böhme, Filozofia i estetyka przyrody, s. 6].

„W samej ekologicznej estetyce przyrody chodzi przede wszystkim o estetyczne doświadczenie przyrody. Nie należy tego jednak rozumieć ani jako zależnego od smaku osądu piękna przyrody lub jako moralnej oceny naturalności, ani jako jakiegoś innego zdystansowanego przyjęcia do wiadomości, lecz jako zmysłowe doświadczenie cielesne będące udziałem człowieka, który znajduje się, mieszka, pracuje i porusza się w jakimś określonym fragmencie przyrody" [tamże, s. 8].

20 "Człowiek epoki oświecenia pojmował siebie jako istotę rozumną - i na tej podstawie definiował swoje ciało. Ciało nie było dla niego tą częścią przyrody, którą jest on sam, lecz raczej związanym z nim fragmentem przyrody, czymś zewnętrznym: u Kartezjusza było inną substancją, u Kanta było zwierzęcością, którą należy przezwyciężyć na drodze cywilizacji, kultywacji i moralizacji, w pedagogice oświeceniowej było zwierzęcością, którą trzeba nieustannie kontrolować i ostatecznie zmusić do milczenia. Człowiek nowożytny bada naturę w sposób zdystansowany i chłodny, na podstawie daleko już posuniętego jej instrumentalnego opanowania" [tamże, s. 25]. W cytatach zauważam „uprzestrzenniony" charakter ciała.

21 G. Böhme, Filozofia i estetyka przyrody, s. 6-7. 
Schmitzem, nazywa ",atmosferami" 22. Ujawniają się one w przedmiotach, rzeczach, ludziach i „emanują". Nie można do nich dotrzeć za pomocą obiektywnej wiedzy, jedynie poprzez doświadczenie cielesne i zmysłowe.

Leszek Żuliński w recenzji trzeciego tomiku Małgorzaty Lebdy podkreśla "atmosferyczny" charakter zawartych w nim wierszy. Krytyk odwołuje się do tytułu zbioru, który docelowo został zmieniony na znaną nam Granice lasu:

Znałem ten tomik już w maszynopisie. Miał pierwotnie nazywać się Mesmery$z m y$. Autorka zrezygnowała $\mathrm{z}$ tego tytułu, ale ja tego słowa pominąć $\mathrm{w}$ recenzji nie mogę, bowiem ono oddaje całą istotę tych wierszy. Przypomnę - za Wikipedią - co to takiego mesmeryzm; otóż jest to popularna na początku XIX wieku teoria Franza Mesmera zakładajaca istnienie emitowanych przez żywe organizmy fluidów odpowiedzialnych u ludzi za uczucia $i$ sympatie ${ }^{23}$.

Nie pomijam tej informacji, która pozwala rozumieć cielesną zmysłowość jako umiejętność odczytywania "energii” emanującej od innych organizmów żywych (nie tylko zwierząt, ale i roślin). W twórczości Lebdy sympatii do zwierząt mało, są często podporządkowane człowiekowi i tym samym zredukowane do roli przedmiotów, materii bez życia. Nie inaczej dzieje się $\mathrm{w}$ wierszu gesty:

gesty

z czasem używamy coraz prostszych słów aż dominują w nas gesty może wierzymy że są w nas ślady prajęzyka być może to słabość albo podstępna mowa choroby wieczne odchodzenie w taki czas musimy opowiadać sobie przeszłość zapewniać się o jej istnieniu pamiętasz jak sierpniowego poranka ojciec przyniósł na swojej ciemnej skórze sine kleszcze? wtedy po raz pierwszy pomyślałam o jego krwi

ale teraz skupmy się na porankach na przełykaniu leków na naklejaniu plastrów nie pomylmy dni

[GL, s. 31]

Odczuciem pierwotnym staje się lęk przed śmiercią uobecniony w chorobie ojca. Stan choroby w sposób bezpośredni ukazuje nam własną cielesność i jej wymiary oraz granice. Oddaliliśmy się od własnego „bycia”, doświadczania zmysłowego, a choroba, jako sytuacja graniczna, na powrót zadomawia nas we własnym ciele. Nie jest to zjawisko przyjemne i pożądane, jednak

22 „Estetykę, do której zmierzamy, można zatem nazwać zarówno teorią usytuowań, jak i teorią atmosfer" [tamże, s. 7].

${ }^{23}$ L. Żuliński, Mesmeryzmy. 
łączy się z pierwotnością: emocją i doznaniem czystym, "atmosferą", którą nie tylko czujemy, ale także obdarzamy osoby i przedmioty przebywające w pobliżu. Kiedy chorujemy, choruje i przestrzeń wokół: „Gdy boli mnie, na przykład, ręka, miejsce «ręka» narzuca się jako absolutnie «tutaj» 24". Choroba ciała to choroba przestrzeni chorującego.

Choroba sprawia, że ciało staje się klaustrofobiczne. Towarzyszące jej częste napady gorączki sprawiają, że rzeczywistość się oddala. Pozostaje to, co najbliżej fizycznie - przestrzeń potęguje swoje znaczenie, pokój chorego staje się epicentrum bólu i tym samym świata. W wierszu gesty choroba zaś uczłowiecza, pozwala na "spóźniony spokój”" 25, utraconą świadomość, wyzwala pierwotny język oparty na zmysłowości.

Odczucie własnej fizyczności to moment przełomowy: poznanie łączy się z kresem życia. Pamiętać zaś to znaczy ciągle żyć. Owo przypominanie sobie jest zespolone z pamięcią ciała (ciałopamiętaniem), które bezpośrednio aktywuje procesy mnemotechniczne $\mathrm{w}$ konkretnych przestrzeniach, zdarzeniach, kontaktach z przedmiotami, innymi osobami. Ciałopamiętanie jest wywoływane impulsem zmysłowym. Myśl o krwi ojca to przypominanie sobie jego „,ciemnej" skóry i „sierpniowego poranka” oraz „,sinych” kleszczy.

Poranek w wierszu to konkretne wydarzenie sensoryczne. "Sierpniowy poranek" jest ciepły, gorący, jest gorączką. Skupić się zaś na poranku, który pozostaje niedookreślony („ale teraz skupmy się na porankach”) znaczy tyle, co nie odczuwać, wyzbyć się wspomnianych wrażeń zmysłowych. Myśl o krwi to rozważanie o ciele. Nie bez przyczyny po wyrazie "krew” następuje spacja, tak charakterystyczna dla twórczości Lebdy. Wydźwięk tego słowa pozostaje $\mathrm{w}$ zawieszeniu, niedomknięciu. Krew jest symbolem narodzin i śmierci, tego, co nieczyste i jednocześnie oczyszczające. To ciecz budząca strach i fascynację, lęk i trwogę, łącząca metafizyczną i religijną sferę ludzkiego życia z tym, co fizyczne, a czasami nawet wulgarne ${ }^{26}$. W wierszu myśl o krwi to także rozważanie o „ojcowiźnie”. Kobieca postać „jest z krwi ojca". Zastanawiając się nad jego krwią pyta ona tak naprawdę o własną tożsamość i własną cielesność. Krew jawi się jako język pierwotny łączący ojca i córkę.

\footnotetext{
24 G. Böhme, Antropologia filozoficzna. Ujęcie pragmatyczne [wykłady z Darmstadt], przeł. S. Czerniak, Warszawa 1998, s. 102.

25 Tamże, s. 3.

26 ,w ostatecznym rozrachunku związek krwi i życia nigdy całkowicie nie przesłania związku krwi i śmierci. Ponieważ jest on zaledwie uświadomiony, nie potrafimy ostatecznie rozdzielić własności dobroczynnych i szkodliwych, szczęśliwych i nieszczęśliwych, co tylko pogłębia tajemniczy, wewnętrznie sprzeczny charakter krwi" [J.-P. Roux, Krew. Mity symbole, rzeczywistość, przeł. M. Perek, Kraków 2013, s. 13].
} 
Ciało chorego jest jednocześnie ciałem córki, przestrzeń skurczyła się do przestrzeni chorego. Kobieta pragnie odrzucić własną cielesność i wspomnienia, aby spowolnić śmierć ojca. Opisana w wierszu przestrzeń to spacja pomiędzy śmiercią a życiem, której realizacja dopełnia się w ciałach bohaterów i ich doświadczeniach sensorycznych. Ciało jest świadkiem bycia pomiędzy.

W kolejnym tomie poetyckim Matecznik Lebda kontynuuje elegijną opowieść o odchodzącym, a potem o umarłym ojcu. „Matecznik” w leśnictwie oznacza przestrzenie „nieskażone” ingerencją człowieka, pozwalające na zachowanie harmonii w ekosystemie. To miejsce współzależności jego mieszkańców, którzy czerpią z niej obustronne korzyści. Odwołując się do metaforycznego znaczenia tytułu, moglibyśmy nadać tomikowi odmienną nazwę: Ojcownik. Ojciec jest główną postacią, wokół której skoncentrowana została cała poetycka materia i rzeczywistość. To on „wydaje na świat” konkretne konstrukcje zdaniowe, często jednak wypowiadane przez córkę. Nakłada się ciało na ciało. Z Matecznika powstał Ojcownik, zaś z niego - Córkownik.

Traktuję wiersze Lebdy jako tę samą historię przewijającą się przez kolejne utwory i tomy, jeden tekst opowiada/zapowiada/kontynuuje następny. Matecznik, chociaż sytuuje ojca w centrum rozważań, paradoksalnie mówi przede wszystkim o poszukiwaniu kobiecej tożsamości, poznawanej w sposób pierwotny i sensoryczny: poprzez ciało i zapisaną w nim mapę przestrzeni pamięci. Jak zauważa Łebkowska: „Owo sięganie do pierwotnej somatyzacji świata i bezpośrednio do cielesności w poszukiwaniu języka poetyckiego i zarazem źródeł twórczości po dziś dzień tworzy istotny wątek w myśleniu o literaturze ${ }^{27 "}$. Lebda wykorzystuje motyw pierwotnego i cielesnego poznawania świata, aby zbudować prywatną narrację o anty-arkadii. Jest to przestrzeń, którą niekoniecznie chce się pamiętać (ponieważ nie można jej odzyskać i uwypukla jedynie ból utraconego), jednak wie się, że należy ją opowiedzieć. Pierwotne doświadczenia pozwalają uwidocznić przestrzeń pomiędzy córką a ojcem, chorobą a zdrowiem, śmiercią a życiem oraz teraźniejszością i przeszłością oraz opowiedzieć historie nigdy niedokończone, czekające na nieustanną lekturę:

\section{bez tytułu (III)}

a jeśli to wszystko dopiero się rozpoczyna? jeśli przyniesie ciemniejsze historie i dłuższe wiersze? uzdrowienie?

[GL, s. 46]

27 A. Łebkowska, Jak ucieleśnić ciało: o jednym z dylematów somatopoetyki, s. 17. 


\title{
Bibliografia
}

Bal Mieke (2012), Wędrujace pojęcia w naukach humanistycznych. Krótki przewodnik, przeł. M. Bucholc, Warszawa: Narodowe Centrum Kultury.

Bator Joanna (2007), Posłowie. Ciała anamorficzne. Kilka uwag filozoficznych, w: Ucieleśnienia. Ciało w zwierciadle współczesnej humanistyki. Myśl-praktyka-reprezentacja, red. A. Wieczorkiewicz i J. Bator, Warszawa: PAN, s. 292-299.

Boryś Wiesław [red.] (2005), Słownik etymologiczny języka polskiego, Kraków: Wydawnictwo Literackie.

Böhme Gernot (1998), Antropologia filozoficzna. Ujęcie pragmatyczne [wykłady z Darmstadt], przeł. S. Czerniak, Warszawa: PAN.

Böhme Gernot (2002), Filozofia i estetyka przyrody. W dobie kryzysu środowiska naturalnego, przeł. J. Merecki, Warszawa: Oficyna Naukowa.

Kunce Aleksandra (2013), Dom - na szczytach lokalności, w: Oikologia. Nauka o domu, red. T. Sławek, A. Kunce, Z. Kadłubek, Katowice: Wydawnictwo Uniwersytetu Śląskiego, s. 58-73.

Kunce Aleksandra (2013), Puste $i$ domowe, w: Oikologia. Nauka o domu, red. T. Sławek, A. Kunce, Z. Kadłubek, Katowice: Wydawnictwo Uniwersytetu Śląskiego, s. $142-167$.

Lebda Małgorzata, (2013) Granica lasu, Poznań: Wydawnictwo WBPiCAK.

Lebda Małgorzata (2016), Matecznik, Poznań: Wydawnictwo WBPiCAK.

Lebda Małgorzata (2009), Tropy, Gniezno: Zeszyty Poetyckie.

Łebkowska Anna (2011), Jak ucieleśnić ciało: o jednym z dylematów somatopoetyki, „Teksty Drugie", nr 4, s. 11-27.

Roux Jean-Paul (2013), Krew. Mity symbole, rzeczywistość, przeł. M. Perek, Kraków: Wydawnictwo Znak.

Sławek Tadeusz (2013), Gdzie, w: Oikologia. Nauka o domu, red. T. Sławek, A. Kunce, Z. Kadłubek, Katowice: Wydawnictwo Uniwersytetu Śląskiego, s. 7-57.

Wiślicz Tomasy (2012), Integralność cielesna jednostki w perspektywie przejścia do nowoczesności - zarys problematyki, w: Somatotes. Cielesność w ujęciu historycznym, red. R. Matuszewski, Warszawa: Wydawnictwo Uniwersytetu Warszawskiego, s. $131-144$.

Żuliński Leszek (2014), Mesmeryzmy, „Latarnia Morska”, 20.01.2014, http://latarniamorska.eu/en/port-literacki/1428-qgranica-lasuq-magorzaty-lebdy.

\section{Soma/spatio/graphies: the Space in-between in the Works of Małgorzata Lebda}

\begin{abstract}
The article aims to interpret the poems of Małorzata Lebda using the "travelling concept" of the space in-between. Desiring to stay close to the poetic text, the author focuses on the various ways in which the
\end{abstract}


soma and the space interact. She does not understand the function of soma/spatio/graphy as merely identifying themes of the body and space in the poem but as illustrating how the two are related. This illuminates the problems and possibilities of contemporary cultural humanities.

Keywords: literary space, expanse, body, illness, travelling concept, poetry 